\title{
MODEL KOMUNIKASI POLITIK DI ERA DUNIA VIRTUALITAS
}

\author{
Supriadi $^{1}$ \\ ${ }^{I}$ Magister Komunikasi dan Penyiaran Islam Fakultas Dakwah dan Komunikasi \\ UIN Sunan Kalijaga, Yogyakarta \\ E-mail: Supriadgochik12@gmail.com,Tlp:+6283129394969
}

\begin{abstract}
Abstrak
Media massa dan politik tidak bisa dipisahkan karena media sebagai saluran komunikasi politik yang sangat efektif. Media massa memainkan peran yang sangat penting dalam peroses politik. Kemampuan media dalam menyampaikan penyiaran untuk menampilkan pesan kepada khalayak luas menjadikan media sebagai objek, media penyiaran merupakan organisasi yang menyebarkan informasi yang berupa produk budaya atau pesan yang dapat mempengaruhi dan mencerminkan budaya dalam masyarakat, seperti halnya aspek politik dan ekonomi. Kondisi politik yang dibangun di dalam berbagi ruang virtual (seperti cyberspace), yang memengaruhi bentuk, penampakan, nilai, dan kebeneran politik itu sendiri. Media merupakan ruang untuk perbuatan pengaruh para elit politik, baik yang berada di dalam pemerintah maupun yang di luar pemerintah, berupaya mendaptkan akses yang lebih lama dan luas untuk mempengaruhi persepsi masyarakat tentang politik, realitas politik, kebijakan dan lembaga pemerintah yang sedang berkuasa.
\end{abstract}

Kata Kunci : Media Massa, Komunikasi Politik, Dunia Virtualitas

\section{Pendahuluan}

Diera digital media menjadi salah satu penyiran yang cukup dipercaya oleh masyarakat, akan tetapi media sering juga keluar dari koridor atau aturanaturan yang telah di tetapkan olek Komisi Penyiaran Indonesia (KPI). Namun media elektronik maupun cetak sering sekali di gunakan oleh para elit sebagi lalat kampanye pada momen pilpres atau pilek.

Para elit menggunakan media sebagai alat untuk menarik simpatisan atau sura masyarakat, media juga tidak mau terlepas sebagi bahan politik yang digunakan oleh orang-orang elit yang memberi kartel atau oportunistik pada saat mendapatkan korsi di pilpers atau pilek. 
Volume 2, No. 1, 2020

P-ISSN: 2655-5166

E-ISSN: 2715-2103

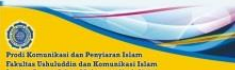

Homepage : http://journal.iaimsinjai.ac.id/indeks.php/retorika

Politik merupakan persilangan antara ilmu politik dan ilmu komunikasi. Pembahsan ini berkutat pada proses penyampaian pesan melalui media yang juga bersifat politis. Sama seperti pesan, media dan saluran politik formal seperti negara dan lembaga-lembaga politik lainnya juga memeiliki kekuatan politik lainnya.

Secara garis besar, politik berkenaan dengan gejala kekuasaan, kewenangan pengaturan, ketaatan dan ketertiban. Jika kita sederhanakan lagi, sama halnya dengan kewenangan dan pengaturan, kekuasaan (power) dan pengaruh (influence) merupakan suatu kesimbangan dan konsekuensi logis. Sedangkan ketaatn dan ketertiban adalah akibat dan tujuan. Dengan demikian, politik politik berkaitan dengan tiga hal utama, yaitu kekeusaan (power), kewenangan (authority), dan ketaatn atau ketertiban (order).

\section{Kajian Teori}

\subsection{Pengertian Politik dan Dunia Virtualitas}

Konsep virtualitas, dalam konteks politik tidak hanya dipahami sebagai sifat kenyamanan yang tercipta akibat mekanisme jejaringan komputer (cyberspace), akan tetapi melingkupi konsep maya dalam pengertian yang lebih luas, yang tercipta di dalam ruang-ruang lebih luas, yang mencakup di dalamnya ruang-ruang televisi, filem, video dan media komunikasi publik lainnya.

Dunia virtual, sebagaimana dikatakan oleh Michel Hardt dan Anthony Negri, adalah dunia yang melampaui ukuran, dalam pengertian bahwa tidak ada mekanisme yang dapat mengukur kekuatan nilai, atau batas, yang hanya mungkin dilakuakan di dalam dunia yang mempunyai batas-batas. Di dalam dunia virtual tidak ada lagi sekala yang tepat dan dapat digunakan untuk mengukur nilai, kekuatan, atau batas tersebut, disebabkan semuanya bergerak dan berpindah kearah konstitusi nilai-niali yang melampaui ukuran. Probelm pengukuran (kekuatan, nilai, batas) di dalam dunia virtualitas disebabkan dunia tersebut dibangun oleh sebuah tempat yang berciri ketak-bertempat-an (non-place). Tidak ada yang disebut tempat dalam pengertian yang sebernernya dalam dunia virtual, yang mengenal batas-batas tritorial. Dengan demikian, salah satu pengertian dunia 
Volume 2, No. 1, 2020

P-ISSN: 2655-5166

E-ISSN: 2715-2103

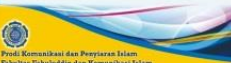

Homepage : http://journal.iaimsinjai.ac.id/indeks.php/retorika

virtualitas adalah seperangkat kekuatan atau bertindak (mengada, mencintai, mentransformasikan, mencipta) yang berada di dalam ketidak berhinggaan, artinya dalam ketidak berbatasan dan ketidak terbatasan (Yasraf A. Piliang: 2005,29).

Komunikasi politik merupakan kajian sangat menarik. Alasannya adalah karena kajian ini memeiliki kajian praktis yang berguna bagi para pelaku dan partisipan politik, baik kalangan elit politik maupun gerakan rakyat. Siapa saja yang melihat bahwa dunia tidak dapat dilepaskan dari reaksi kekuasaan, maka ia akan meyakini bahwa relasi kekuasaan tidak akan dapat dilepaskan dari proses komunikasi (Nurani Soyomuki: 2013, 7-17).

Komunikasi politik merupakan persilangan antara ilmu politik dan ilmu komunikasi. Pembahsan ini berkutat pada proses penyampaian pesan melalui media yang juga bersifat politis. Sama seperti pesan, media dan saluran politik formal seperti negara dan lembaga-lembaga politik lainnya juga memeiliki kekuatan politik lainnya.

Secara garis besar, politik berkenaan dengan gejala kekuasaan, kewenangan pengaturan, ketaatan dan ketertiban. Jika kita sederhanakan lagi, sama halnya dengan kewenangan dan pengaturan, kekuasaan (power) dan pengaruh (influence) merupakan suatu kesimbangan dan konsekuensi logis. Sedangkan ketaatn dan ketertiban adalah akibat dan tujuan. Dengan demikian, politik politik berkaitan dengan tiga hal utama, yaitu kekeusaan (power), kewenangan (authority), dan ketaatn atau ketertiban (order).

Dalam kehidupan kita sehari-hari istilah politik sudah tidak begitu asing lagi terdengar di telinga, karena segala sesuatu yang dilakukan atas dasar kepentingan kelompok atau kekuasaan, sering kali diatasnamakan kepentingan kelompok tersebut. Dalam mekanisme pengaturan tersebut tergambar kewenangan pemerintah untuk mengatur dan memakas. Kewenangan tersebut terlihat dari adanya sanksi atau denda untuk sebuah ketidaktatan pada mekanisme.

Namun di negara ini politik berkembang yang begitu pesat tidak bisa terlepas dari dua kalasifikasi yaitu: politik Kartel merupakan politik yang menopang pemerintah untuk melakukan koalisi, sedangkan politik Oportunistik 
Volume 2, No. 1, 2020

P-ISSN: 2655-5166

E-ISSN: 2715-2103

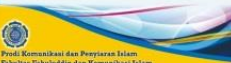

Homepage : http://journal.iaimsinjai.ac.id/indeks.php/retorika

merupakan politik lewat bagi-bagi kursi atau kekuasaan. Peran lembaga politik yang semestinya untuk mewujudkan dan kesejahteraan masyarakat, tersandara oleh kepentingan-kepentingan yang terselubung yang bergelut di dunia perpolitikan (Lukas S. Ispandriarno: 2014, vii).

Bayangkan sebuah dunia politik, yang di dalamnya tidak ada ruang publik, melainkan ruang digital politik, tidak ada kebenaran politik melainkan manipulasi politik, tidak ada realitas politik melainkan fatamorgana politik, tidak ada kebijakan politik melainakan permainan bebas politik, tidak ada transendensi politik melainkan imanensi politik inilah dunia politik.

Setidak-tidaknya isu utama yang mengemuka di dalam wacana pemikiran politik, dewasa ini sebagai akibat dari berbagai perubahan yang disebabkan dari pengaruh perkembangan ilmu pengetahwan dan teknologi mutakhir beserta bebragai efek sosial kemanusiaan yang di timbulkannya. Perkembangan yang disebut abad informasi, abad citra atau abad virtual akhir-akhir ini telah memengaruhi bagaimana politik itu di pandang. Tiga isu sentral politik di dalam abad informasi ini adalah:

Pertama, geopolitik yaitu terjadinya perubahan mendasar tentang fungsi atau wilayah tritorial, khususnya bagaimana politik dipandang di dalam dunia yang tanpa sekat dan di dalam era transparansi yang di ciptakan oleh abad informasi dan globalisasi. Pemahaman tentang politik, dalam pengertiannya yang paling luas, kini sudah tidak lagi sepenuhnya bergantung pada keberadaan tempat, wilayah, atau tritorial sebagai suatu kesatur utuh dan menjadi prasyarat politik.

Kedua, politik ruang yaitu apa yang di dalam teori-teori politik secara tradisional disebut ruang publik kini mengalami berbagai transformasi mendasar, sebagai akibat dari perkembangan ruang-ruang maya yang diciptakan dalam jaringan teknologi informasi. Di dalam ruang informasi tersebut, ruang publik fisik diambil alih dan di ubah ke arah ruang publik virtual. Perkembangan teknologi informasi mutakhir telah menciptakan pergeseran atau imigrasi masyarakt politik dari ruang publik fisik ke dalam ruang publik virtual, yang di dalamnya berbagai aktivitas politik kini dilakukan secara virtual. 
Volume 2, No. 1, 2020

P-ISSN: 2655-5166

E-ISSN: 2715-2103

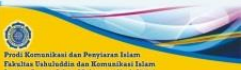

Homepage : http://journal.iaimsinjai.ac.id/indeks.php/retorika

Ketiga, persoalan politik waktu yaitu bagaimana tempo kehidupan di dalam masyarakat informasi yang di picu oleh berbagai bentuk teknologi informasi, yang telah menggiring berbagai aktivitas politik ke dalam tempo kecepatan dan percepatan yang tinggi, yang didalamnya tahap tertentu berpengaruh pada esensi politik itu sendiri.

Di dunia politik yang dibangun oleh tempo yang cepat tersebut, kekeuasaan politik tidak dapat lagi dibangun dalam bentuk kekuasaan tritorial itu sendiri, akan tetapi lebih jauh lagi kekuasaan atas kecepatan, beserta pengetahuan yang membangun.

\subsection{Media Massa}

Media massa memiliki peranan penting dalam kehidupan masyarakat Indonesia. Dalam hal ini, media massa hidup sebagai penyambung lidah bahkan jembatan informasi bagi masyarakat. Media massa pun menjadi sumber informasi yang dapat membentuk pandangan publik, selalu menyajikan beragam informasi yang aktual dan dikonsumsi masyarakat secara luas. Media menyajikan informasi atau berita yang mampu menyebabkan masyarakat menjadi percaya terhadap segala informasi yang disajikan. Informasi yang diterima oleh masyarakat belum tentu sepenuhnya atau secara lengkap diserap, sehingga akan menimbulkan distorsi pesan. Dengan terjadinya distorsi maupun disinformasi, maka akan dapat menghasilkan sikap yang salah. Sikap yang salah inilah yang nantinya akan memberikan dampak buruk bagi masyarakat (Wawan Kuswandi: 2008, 11).

Selain itu, media massa menyajikan informasi yang diolah sedemikian rupa agar menjadi berita hingga kemudian dapat membentuk dan menciptakan citra bagi suatu instansi maupun individu. Pertanyaan yang mendasar, apakah media menggambarkan dunia sebagaimana fakta dan peristiwa (keadaan dunia), berdasarkan pikiran manusia khalayak media, atau media menciptakan pemahaman sendiri atas dunia berdasarkan kecenderungan pemahaman organisasi dan pengelola media.

Informasi sudah menjadi kebutuhan manusia yang esensial untuk mencapai tujuan. Melalui informasi manusia dapat mengetahwi peristiwa yang 
Volume 2, No. 1, 2020

P-ISSN: 2655-5166

E-ISSN: 2715-2103

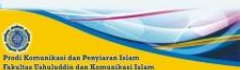

Homepage : http://journal.iaimsinjai.ac.id/indeks.php/retorika

terjadi di sekitarnya, memperluas cakrawala pengetahwannya, sekaligus memahami kedudukan serta prannya dalam masyarakat.

Media massa, pada hakekatnya beupaya memotifasi masyarakat untuk berpartisipasi aktif dan keritis dalam menyoroti berbagai persoalan di masyarakat. pres menjadi mediator antara pemerintah dengan masyarakat. Pres menjadi agen pembaruan dalam segala kompleksitasnya yang berorientasi pada kebenaran.

Indonesia sebagai negara berkembang, perlu memformulasikan konsep aturan maen dari proses komunikasi dan informasi media massa. Dalam perkembangannya, pres di Indonesia banyak mengalami pasang surut serta tumpang tindih (over lapping), khususnya dari segi hukum yang mengatur pola hidup antara pers, pemerintah dan masyarakat.

Media massa di Indonesia hendaknya jangan menganggap bahwa masyarakat adalah pasar yang potensial serta dapat dipolitisi sedemikian rupa hingga menjadikannya sebagai audien yang setia atau pennurut. Karena itu, dalam menjalankan fungsinya, media massa harus mampu berdiri tetap di tengah (pers, masyarakat, dan pemerintah), mengingat masyarakat Indonesia sebagai resources yang sangat potensial dalam mengisi pembangunan.

Kemampuan media dalam menyampaikan penyiaran untuk menampilkan pesan kepada khalayak luas menjadikan media sebagai objek, media penyiaran merupakan organisasi yang menyebarkan informasi yang berupa produk budaya atau pesan yang dapat mempengaruhi dan mencerminkan budaya dalam masyarakat, seperti halnya aspek politik dan ekonomi. Media massa khususnya media penyiaran merupakan suatu sistem tersendiri yang merupakan bagian dari sistem kemasyarakatn yang lebih luas (Wawan Kuswandi: 2008,12).

a. Media Massa Sebagai Sumber Informasi Politik

Sebelum era media, masyarakat tidak banyak tahu apa yang dilakukan para wakil rakyat. Kini, berekat media semuanya dapat diketahui. Bagi publik, media telah menerapkan sebuah fungsi pengawasan yang memberikan informasi tentang aktivitas politk yang dulunya tidak diketahui namun sekarang bisa diketahui secara keseluruhan. 
Volume 2, No. 1, 2020

P-ISSN: 2655-5166

E-ISSN: 2715-2103

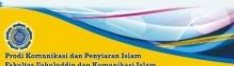

Homepage : http://journal.iaimsinjai.ac.id/indeks.php/retorika

Mayoritas masyarakat atau mungkin keseluruhannya mengetahui informasi tentang politik dari media massa, baik media lokal, regional, nasional, bahkan internasional. Dari hari kehari, masyarakat Indonesia, baik yang ada di desa terlebih yang ada di kota, dikepug oleh berbagai informasi.

b. Fungsi Media Massa dalam Politik

Media massa selalu menjadi ajang perhatian dan perbuatan para penyandang modal karena media massa merupakan lahan yang sangat menguntungkan dan begitu penting, terutama di negara maju dan negara penganut sistem demokrasi. Pada lain sisi, pemerintah pun sangat berkepentingan terhadap media massa. Dalam kegiatan komunikasi politik, fungsi media massa:

Pertama, fungsi informasi. Media massa selalu menjadikan sumber informasi dalam berbagai tayangan atau pristiwa politik yang terjadi diberbagai belahan bumi termasuk aktivitas aktor politik dengan sikap dan prilaku politik lainnya.

Kedua, fungsi partisipasi. Hal ini menunjukkan bahwa setiap unsur berita harus mampu membangkitkan kesetraan masyarakat dalam mendukung segala kebijakan pemerintah yang berkait dengan kepentingan masyarakat.

Ketiga, fungsi sosialisasi dan pendidikan politik. Fungsi ini untuk meningkatkan kualitas rujukan masyarakat dalam menerima dan sistem nilai atau sistem politik yang sedang berlangsung.

Keempat, fungsi politisasi. Yaitu mengembangkan budaya politik. Fungsi ini merupakan fungsi penentu terhadap fungsi-fungsi yang lain karena fungsi ini membentuk pola prilaku yang memberi warna dominan terhadap karakter suatu bangsa.

Kelima, fungsi integrasi bangsa. Fungsi ini merupakan syarat mutlak bagi kehidupan negara dalam mencapai tujuan. Karena itu, media massa harus mampu mengembangkan pemikiran-pemikiran integralistik dalam artian bahwa media massa harus mengintegrasiakan etnis budaya, sukuisme, provinsialisme dan pemikiran-pemikiran lain ke pemikiran nasionalistik (Roni Tabroni: 2012, 95). 
Volume 2, No. 1, 2020

P-ISSN: 2655-5166

E-ISSN: 2715-2103

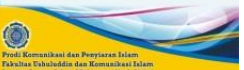

Homepage : http://journal.iaimsinjai.ac.id/indeks.php/retorika

Media massa memiliki kontribusi yang sangat signifikan dalam konteks partisipasi politik. Dalam tangga tertentu, media massa dapat menyediakan menu pilihan bagi khalayak. Sajian dalam media massa beragam sehingga dapat memperkaya rujukan komunikasi. Informasi-informasi politik dapat diikuti dari sajian atau tayangan media massa.

c. Kebebasan Media Massa

Setelah terpasang selama 32 tahun, pada masa orde informasi media menemukan kebebasannya. Informasi yang disampikan begitu terbuka melalui sapek politik, ekonomi, budaya, hingga persoalan hukum. Kebebasan media massa ini memberikan kesempatan kepada publik dan elit politik untuk melakukan tukar informasi sekaligus kontrol sosial secara terbuka.

Kebebasan ini menjadi lebih penting sebab hakikat media massa dalam pandangan Rochajat adalah untuk memberi manfaat bagi kepentingan untuk manusia. Media massa sebagai sarana untuk mengembangak sarana jalinan komunikasi antarmanusia yang berada dalam berbagi geonatur dan geokultur pada pelanet bumi ini. Karena itu, media massa menghendaki kebebasan di tengah-tengah kehidupan manusia.

Secara filosofis, kehadiran media massa adalah hakikat produk berpikir manusia yang dapat membantu manusia untuk menemukan simbol-simbol ketentraman dan keharmonisan sebagaiman yang ada di alam ini. Segala apa yang ada di alam ini adalah sifat-sifat keserasian, kedamaian, keadilan, keharmonisan, dan ketentraman.

Kondisi semacam ini kata Rochajat, mengandung makna bahwa kehadiran media massa berada di dalam wilayah Das Sollen, alam ideal. Alam yang dicita-citakan. Namaun pada waktu media massa melakukan tugas dan fungsinya yang memasuki wilayah Das Sein, yaitu dunia nyata atau dunia empiris, adakalnya media massa bergeser dari Das Solleny-nya, kemudian terjebak pada kondisi Das Sein-nya. Tidak salah ungkapan bahwa tidak selamanya cocok antara alam ideal dengan dunia nyata. 
Retortea RETORIKA

Jurnal Kajian Komunikasi dan Penyiaran Islam

Volume 2, No. 1, 2020

P-ISSN: 2655-5166

E-ISSN: 2715-2103

Homepage : http://journal.iaimsinjai.ac.id/indeks.php/retorika

\subsection{Kampanye di Media}

Di Indonesia kampanye sering disebut dengan pawai motor, pertunjukan hiburan oleh para artis, pidato berapi-api dari para juru kampanye penuh propaganda, agitasi, caci maki, dan ledakan-ledakan sinis yang menyinggung kontestan lain. Dengan cara-cara seperti itu, pengertian kampanye sudah banyak disalhartikan karena realitas lapangan sering kali tidak sesuai tujuan kampanye.

Kampanye adalah aktivitas komunikasi yang ditujukan untuk mengaruhi orang lain agar ia memiliki wawasan, sikap dan prilaku sesuai dengan kehendak atau keinginan penyebar atau pemberi informasi. Dalam komunikasi politik kampanye dimaksudkan untuk memobilisasi dukungan terhadap suatu hal atau seorang kandidat. Sedangkan menurut Imawan kampanye adalah upaya persuasuif untuk mengajak orang lain yang belum sepaham atau belum yakin pada ide-ide yang kita tawarkan, agar mereka bersedia dan mendukung.

a. Pemasaran Politik

Pemasaran politik adalah sebuah konsep baru yang belum begitu lama dikenal dalam kegiatan politik. Ia merupakan konsep yang diintroduksi dari peneybaran ide-ide sosial di bidang pembangunan dengan meniru cara-cara pemasaran komersial, tetapi orientasinya lebih banyak pada tataran penyadaran, sikap, dan perubahan prilaku untuk menerima hal-hal baru. Pemasaran sosial berorientasi pada upaya untuk memasyarakatkan ide-ide sosial terutama dalam hal perubahan prilaku masyarakt untuk menerima pembaruan.

Dari konteks aktivitas politik, pemasran politik dimkasudkan adalah penyebarluasan informasi tentang kandidat, partai, dan program yang dilakukan oleh aktor-aktor politik melalui saluran-saluran komunikasi tertentu yang di tunukan kepada segmen (sasaran) tertentu dengan tujuan mengubah wawasn, pengetahuan, siakp, dan prilaku para calon pemilih sesuai dengan keinginan pembri informasi.

b. Tim Sukses dan Pemasaran Politik

Sebuah kegiatan pemasaran politik sedapat mungkin yang diawali dengan kegiatan pemebentukan tim yang disebut "tim sukses”. Tim suskses 
Volume 2, No. 1, 2020

P-ISSN: 2655-5166

E-ISSN: 2715-2103

Homepage : http://journal.iaimsinjai.ac.id/indeks.php/retorika

yang dirkrut dari tenaga-tenaga potensial sesuai dengan tugas dan fungsinya.

Sebuah tim suskes biasanya terdiri dari sebagai berikut:

1. Penasehat, berfungsi memeberi masukan dalam hal strategi dan langkahlangkah yang perlu diambil oleh partai atau acalon untuk mencapai tujuan yang diinginkan.

2. Tim Ahli, adalah kelompok ahli yang diangkat sesuai dengan biddangnya. Biasanya tugas tim ahli ialah menyususn program yang dibawa oleh para calon, memberi subtansi atau tema terhadap isi pidat yang dibawakan, dan mem-back up calon jika ada pertanyaan-pertanyaan yang menyangkut bidang keahliannya (Hafied cangara: 2009, 275).

3. Tim Riset dan Litbang

Tim riset dan litbang adalah sekelompok orang peneliti yang bertugas untuk dikumpulkan informasi yang relevan dengan partai, misalnya persepsi masyarakat terhadap citra partai, pendapat masyarakat terhadap kapabilitas calon yang diusung, peta politik pemilih, dan juga melakukan pelatihanpelatihan untuk para kader dalam bidang-bidang yang dibutuhkan.

4. Tim Pengumpulan Data

Bagi yang ingin maju dalam pencalonan jabatan publik, seperti anggota legislatif tidak hanya memerlukan banyak waktu energi dan pendukung, tetapi juga memerlukan dana yang tidak kecil untuk mempromosikan diri, kebijakan, pikiran-pikirannya.

5. Tim Kampanye, mereka yang merncanakan dan menggerakkan kampanye untuk memasarkan calon yang diusung partai politik.

6. Tim Penggalangan Massa, mereka adalah orang-orang yang direkrut untuk menggalang massa, baik untuk kepentingan pengumpulan suara maupun show force untuk menjunjukkan kekuatan partai kepada masyarakat dan calon pemilih.

7. Tim Hubungan Antar daerah

Tim ini merupakan orang-oarng yang dipercaya untuk menangani hubungan antar pengurus pusat dan pengurus wilayah dan cabang yanga ada di ibukota provensi dan kabupaten. 
Volume 2, No. 1, 2020

P-ISSN: 2655-5166

E-ISSN: 2715-2103

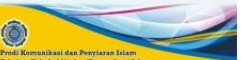

Homepage : http://journal.iaimsinjai.ac.id/indeks.php/retorika

8. Tim Pengamat

Tim ini dibentuk untuk mengamati dan mengawasi tindak tanduk lawan politik yang membahayakan citra partai atau calon. Tim pengamat mengumpul dan menyampikan informasi (data) ke pemimpin partai untuk segera diambil tindakan dalam mengatasi hal-hal tersebut.

9. Tim pengaman

Tim ini sangat penting, terutama untuk memeberi perlindungan keamanan kepada calon yang diusung oleh partai sebab di negara-negara yang memilik kemanan yang belom setabil, perlindungan kepada calon, apalagi di posisi kepersidenan sangat diperlukan.

10. Tim Pengumpul Suara

Mereka terdiri dari orang-orang yang di rekrut karena pengarunya yang sangat besar di tengah-tengah masyarakat. Merka biasanya memiliki sosial ekonomi yang terpandang, tokoh masyarakt tokoh agam yang berada di masing-masing daerah.

\subsection{Etika Jurnalistik}

Kode Etik Jurnalistik adalah ikrar yang bersumber pada hati nurani wartawan dalam melaksanakan kemerdekaan mengeluarkan pikiran yang dijamin sepenehnya oleh pasal 28 UUD 1945, yang merupakan landasan konstitusional wartawan dalam melaksanakan tugas jurnalistiknya.

Kemerdekaan mengeluarkan ide atau pikiran ialah hak paling mendasar bagi seorang jurnalistiknya, yang wajib dijunjung tinggi dan di hormati oleh semua pihak. Wartawan bersama seluruh masyarakat, wajib mewujudkan perinsip-prinsip kemerdekaan pers yang profesional dan bermartabat. Tugas dan tanggungjawab yang luhur itu hanya dapat dilaksanakan, apabila wartawan selalu berpegang teguh kepada kode etik jurnalistik.

Mengingat perjuangan wartawan bagian yang tidak dapat dipisahkan dari perjuangan bangsa Indonesia. Maka selain bertanggungjawab dari hati nuraninya, setiap wartawan wajib bertanggungjawab kepada Tuhan yang Maha Esa, negara dalam melaksanakan hak, kewajiban, dan tanggungjawab sesuai dengan kode etik jurnalistik. 
Volume 2, No. 1, 2020

P-ISSN: 2655-5166

E-ISSN: 2715-2103

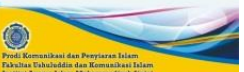

Homepage : http://journal.iaimsinjai.ac.id/indeks.php/retorika

Kode etik yang mengatur profesi wartawan Indonesia anggota PWI adalah kode etik jurnalistik PWI yang pertama kalinya disahkan dalam kongers PWI pada bulan Feberwari 1947. Kemudian professional code ini mengalami beberapa kali perubahan dan penyempurnaan terakhir disahkan Kongers XXI PWI, 2-5 Oktober 2009 di Palangkaraya, Kalimantan Tengah. Dengan demikian tegaknya professional code ini sangat mengandalkan pada "kata hati" atau "hati nurani" wartawan itu sendiri (Hikmat dan Purnama Kusumaningrat: 2016, 105).

a. Embargo

Salah satu ketentuan yang ditetapkan dalam Kode Etik Jurnalistik adalah lambang embargo dan off-the-record. Kedua lambang itu hampir sama dan tidak dapat dibedakan. Contohnya kami temukan disini kasus embargo yang sekaligus merupakan kasus off-the-record dimana sumber berita meminta kepada wartawan yang mewawancarainya agar berjanji bahwa informasi yang ia sampaiakan tidak dapat di samapaika atau dimuat melainkan hanya sebagai pengetahwan wartawan saja.

Pasal 14 Kode Etik Jurnalistik PWI yang berbunyi; "wartawan indonesia menghormati embargo bahan latar belakang, dan tidak menyiarkan informasi yang oleh sumber berita tidak dimaksudkan sebagai bahan berita serta tidak menyiarkan keterangan 'off-the-record' atas kesepakatan dengan sumber berita." Penejlasan pasal 14 kode etik jurnalistik, embargo yaitu permintaan untuk penundaan penyiaran suatu berita samapi waktu yang ditetapkan oleh sumber berita.

b. Off-the-reord

Istilah off-the-record meskipun pengertian hampir sama dengan embargo, yaitu sama-sama merupakan permintaan dari sumberberita untuk tidak penyiarkan keterangan yang di berikan oleh sumber berita. Keterangan yang diberikan secara off-the-reord sebaiknya jangan diterima. Artinya informasi atau keterangan yang diberikan kepada wartawan dengan syarat tidak untuk disiarkan janganlah diterima, penolakan ini sebaiknya dilakukan kalo tidakmau ketinggalan kereta dalam berita. 
Volume 2, No. 1, 2020

P-ISSN: 2655-5166

E-ISSN: 2715-2103

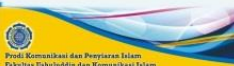

Homepage : http://journal.iaimsinjai.ac.id/indeks.php/retorika

Pada praktiknya acapkali terjadi, bahwa hal yang diminta untuk diberlakukan sebagai off-the-reord sudah diketahui si wartawan sebelumnya. Dalam hal ini demikian, si wartawan dapat menjelaskan kepada sumber yang meminta off-the-reord, dahwa informasi sudah diketahui lebih dahulu.

c. Menyembunykan Identitas Sumber Berita

Menyembunyikan identitas sumber berita itu layak dilakukan ketika yakin tentang keakuratan informasi sumber berita, atau ketika menyebutkan identitasnya akan menempatkan sumber berita dalam posisi yang melakukan, mencurigakan, dan membahayakan dirinya. Atau membuat sumber berita sama baiknya dengan tanpa menyebutkan.

d. Delik Pers

Delik pers berasal dari dua kata delik dan pers. Delik berasal dari bahasa Belanda delict yang artinya tindakan pidana atau pelanggaran. Kata pers yaitu mengacu pada pengertian komunikasi yang dilakukan dengan perantaraan barang cetakan. Tetapi sekarang pers itu termasuk juga kegiatan komunikasi yang dilakukan dengan media elektronik maupun media cetak. Delik pers artinya semua tindakan pidana atau pelanggaran yang dilakukan melelui media massa. Delik pers merupakan istilah yang digunakan untuk menyebutkan kasus-kasus yang berkaitan dengan pers. Sebenarnya delik pers bukan merupakan hukum. Delik pers hanya sebutan untuk menamai pasal-pasal KUHP yang berhubungan dengan pers.

e. Kepribadian Dan Integritas Wartawan

Wartawan harus memiliki kepribadian dalam arti ketuhanan dan keteguhan jati diri serta integritas dalam arti jujur, adil, arif dan terpercaya. Keperibadian dan integritas wartawan yang ditetapkan di dalam kode etik jurnalistik mencerminkan tekad PWI mengembangkan dan menetapkan sosok wartawan sebagai profesional, penegak kebeneran, nasionalis, konstitusional dan demokrat serta beriman kepada Tuhan Yang Maha Esa. 
Volume 2, No. 1, 2020

P-ISSN: 2655-5166

E-ISSN: 2715-2103

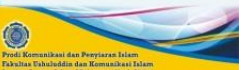

Homepage : http://journal.iaimsinjai.ac.id/indeks.php/retorika

Menurut data Dewan Pers, wartawan sering melakukan pelanggaran kode etik jurnalistik Bentuk pelanggarannya antara lain: ${ }^{1}$

1. Berita tidak berimbang, berpihak, tidak ada verifikasi, dan menghakimi.

2. Mencampurkan fakta dan opini dalam berita

3. Data tidak akurat

4. Keterangan sumber berbeda dengan yang dikutip di dalam berita

5. Sumber berita tidak kredibel

6. Berita mengandung muatan kekerasan.

\section{Kesimpulan}

Kondisi politik yang dibangun di dalam berbagi ruang virtual (seperti cyberspace), yang memengaruhi bentuk, penampakan, nilai, dan kebeneran politik itu sendiri. Media merupakan ruang untuk perbuatan pengaruh para elit politik, baik yang berada di dalam pemerintah maupun yang di luar pemerintah, berupaya mendaptkan akses yang lebih lama dan luas untuk mempengaruhi persepsi masyarakat tentang politik, realitas politik, kebijakan dan lembaga pemerintah yang sedang berkuasa.

Sementara itu media juga menjadi salah satu aktor dalam dunia politik institusional yang punya nilai-nilai untuk diperjuangkan. Salah satu nilai tersebut adalah fungsi demokratis media sebagi lembaga penjaga yang sedang berkuas.

Media massa dan politik tidak bisa dipisahkan karena media sebagai saluran komunikasi politik yang sangat efektif. Media massa memainkan peran yang sangat penting dalam peroses politik. Ia memiliki kemampuan untuk membuat orang cemerlang dalam karir politiknya. Selain media cetak dan media elektronik, seiring dengan bertambahnya pengguna internet saat ini, internet dapat dijadikan media kampanye yang efektif.

\footnotetext{
${ }^{1} \mathrm{Ibd} ., 303$
} 


\section{DAFTAR PUSTAKA}

Hafied cangara," Komunikasi Politik, konsep teori dan strategi," (Penerbit: Pt Rajagrafindo Persada. Jakarta, 2009).

Hikmat Kusumaningrat dan Purnama Kusumaningrat, Jurnalistik Teori dan Praktek, (Penerbit:Pt Remaja Rosdakarya, Bandung 2016).

Lukas S. Ispandriarno," Media dan Politik, siakp pers terhadap pemerintahan koalisi di Indonesia," (penerbit: IKAPI DKI Jakarta. Jakarta, 2014).

Nurani Soyomuki," Komunikasi Politik," (Penerbit, Intrans Publising. Malang, 2013).

Roni Tabroni," Komunikasi Politi pada era Multimedia," (penerbit: Simbiosa Rekatama Media. Bandung, 2012).

Wawan Kuswandi,"Komunikasi Massa, Analisis Intraktif Budaya Massa,"(Penerbit, PT Rineka Cipta. Jakarta 2008).

Yasraf A. Piliang,"Transfolitika, Dinamika Politik di dalam Era Virtualitas," (Perpustakaan Nasional: Katalog dalam Terbitan KDT. Yogyakarta, 2005). 